\title{
Gattopardo economics: the crisis and the mainstream response of change that keeps things the same
}

\author{
Thomas I. Palley \\ AFL-CIO, Washington, DC, USA
}

Gattopardo constitutes change that keeps things the same. Gattopardo is relevant for understanding the economics profession's response to the financial crash of 2008. This paper explores gattopardo economics as it applies to the issues of the macroeconomics of income distribution; the global financial imbalances; and inflation policy. Gattopardo economics adopts ideas developed by critics of mainstream economics, but it does so in a way that ignores the thrust of the original critique and leaves mainstream analysis unchanged. Gattopardo economics makes change more difficult because it deceives people into thinking change has taken place. By masquerading as change, it crowds-out space for real change. That makes exposing gattopardo economics a matter of vital importance.

Keywords: gattopardo economics, income distribution, global financial imbalances, inflation policy

JEL codes: $A 11, A 14, A 14, E 00$

\section{INTRODUCTION}

Il Gattopardo (The Leopard) is a sweeping movie, based on the novel by Giuseppe Tomasi di Lampedusa, about social tumult and class conflict in Sicily in the 1860s. Directed by Luchino Visconti and starring Burt Lancaster, the film follows the Prince of Salina who is intent on preserving the existing aristocratic class order in the face of a rising bourgeoisie. As the crisis grows, Tancredi, the prince's wily nephew, speculates that things must change if they are to remain the same. And they do. After the revolution, the old aristocracy remains on top, allied via marriage with the new urban elite.

The concept of gattopardo is directly relevant for understanding the response of the economics profession since the financial crash of 2008. The response has been gattopardo economics, which is change that keeps things the same.

This paper explores gattopardo economics as it applies to the issues of the macroeconomics of income distribution; the global financial imbalances and their role in fomenting the crisis; and inflation policy. Gattopardo economics takes on board ideas developed by critics of mainstream economics, but it does so in a way that ignores the thrust of the original critique and leaves mainstream analysis unchanged.

Gattopardo economics makes change more difficult because it deceives people into thinking change has taken place. By masquerading as change, it crowds-out space for real change. That makes exposing gattopardo economics a matter of vital importance. ${ }^{1}$

1. Exposing gattopardo economics is also an extremely difficult task because intellectual critique and exposure is easily mistaken as personal attack. 


\section{THE STRUCTURAL KEYNESIAN ACCOUNT OF THE CRISIS}

Gattopardo economics works by incorporating ideas of critics - especially Keynesians into mainstream economics. However, it does so in a way that strips the ideas of their critical content. Moreover, it almost never acknowledges the critical paternity of the ideas.

To illustrate how this practice has applied since the eruption of the financial crisis in 2008, I begin by briefly detailing my own structural Keynesian account (Palley 2008; 2009; 2012a) of the financial crisis, the Great Recession, and the Great Stagnation. This account has similarities with other accounts developed by other Keynesian and heterodox economists (see, for instance, Foster/Magdoff 2009; Duménil/Lévy 2011).

The structural Keynesian account argues that the cause of the crisis was flawed economic policies rooted in the neoliberal economic paradigm that guided economic thinking for 30 years prior. The deep origins of the crisis are to be found in the change of economic paradigm that occurred in the late 1970s and early 1980s.

From 1945 to 1975 , the US economy was characterized by a 'virtuous circle' Keynesian growth model built on full employment and wage growth tied to productivity growth. This model is illustrated in Figure 1. The logic was that productivity growth drove wage growth, which fuelled demand growth and created full employment. That provided an incentive for investment which drove further productivity growth. This model held in the US and, in one form or another, it held throughout the global economy - in Europe, Canada, Japan, Australia, Mexico, Brazil, and Argentina.

After 1980, the virtuous circle Keynesian growth model was replaced by a neoliberal growth model. There were two key changes. First, policymakers abandoned the commitment to full employment and replaced that commitment with a focus on low inflation targeting. Second, policy helped corporations sever the link between wages and productivity growth. These changes created a new economic model (Palley 2005). Before 1980, wages were the engine of demand growth. After 1980, debt and asset price inflation became the engines of demand growth.

The new model can be described as the 'neoliberal policy box' which is illustrated in Figure 2. The box pressures workers from all sides. Globalization puts workers in international competition via global production networks and free trade. The small government agenda attacks the legitimacy of government and pushes relentlessly for deregulation regardless of dangers. The labor market flexibility agenda attacks unions and labor market supports such as minimum wages, unemployment benefits, employment protection, and employee rights. Abandonment of full employment puts workers under duress, while monetary policy is conducted with an eye to low inflation targeting and support of

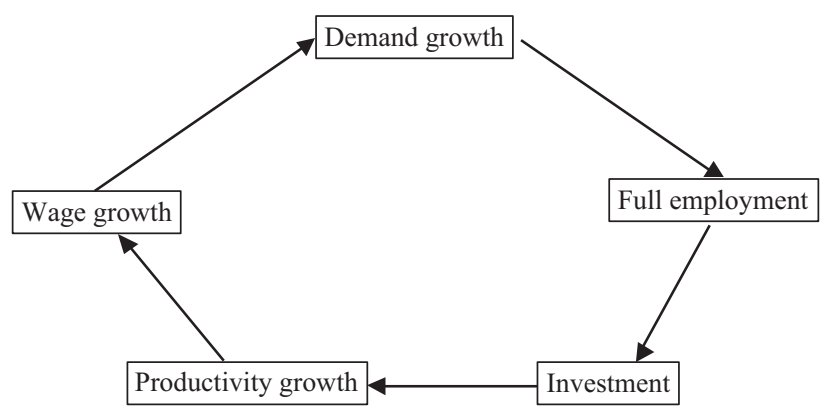

Figure 1 The 1945-1975 virtuous circle Keynesian growth model 


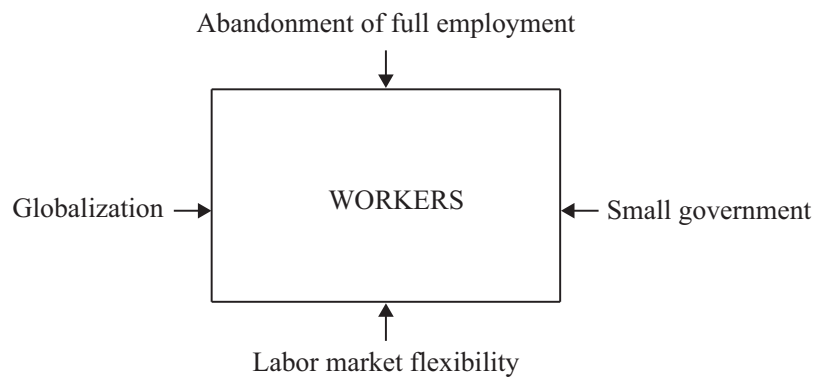

Figure 2 The neoliberal policy box

financial interests. Finance therefore squeezes wages through both public policy and through control over corporations exercised via deregulated financial markets.

The neoliberal policy box was implemented on a global scale, in both the North and South, which multiplied its impact. That is the significance of the "Washington Consensus which was enforced by the IMF and World Bank. In the 1980s and 1990s many emerging market countries needed financial assistance to escape the debt crisis of the early 1980s. The IMF and World Bank made adoption of the neoliberal policy box the condition for getting assistance. That was the significance of the 'conditionality' and 'structural adjustment' debate. In one form or another, the box was implemented globally - in Europe, the US, Canada, Mexico, Argentina, Brazil, Chile, Australia, and South Africa.

The structural Keynesian account also makes clear the role of finance in the crisis. By fostering wage stagnation and increased income inequality, the neoliberal model inevitably undermined the income and demand generation process. That created a growing structural 'demand gap,' and the role of finance was to fill that gap. Financial deregulation, financial innovation, speculation, and old-fashioned lending fraud enabled finance to fill the demand gap by lending to consumers and inflating asset prices. However, by creating a 30-year credit bubble, these developments obscured the negative demand effects of wage stagnation and widening income inequality.

The US trade deficit and associated global financial imbalances also play an important role in the structural Keynesian account of the crisis. As noted earlier, corporate globalization is a central element of the neoliberal policy box, and globalization is the door through which the global financial imbalances enter. From a structural Keynesian perspective, the global imbalances were not a problem that suddenly emerged in the 2000s. Instead, they were a long-running and inevitable outcome of corporate globalization. ${ }^{2}$ This is clearly illustrated in Table 1 which shows the US trade deficit as a percentage of GDP by business cycle peak for the period 1960-2007. Up until 1980 the US trade account was roughly balanced. After that, it started to steadily and persistently increase, reaching 5.7 percent of GDP in 2007. The abrupt worsening of the deficit after 1980 corresponds to the turn to neoliberalism.

Pre-1980, economic policymaking was dominated by Keynesian logic, and trade deficits were viewed with concern as they represented a leakage of aggregate demand (AD). After 1980, neoliberal policymakers viewed trade deficits as semi-virtuous because trade

2. For a detailed discussion of alternative explanations of the global imbalances, see Palley (2012a: ch7). 
Table 1 The US goods and services trade deficit by business cycle peaks, 1960-2007

\begin{tabular}{lccc}
\hline Peak year & Trade deficit (\$ millions) & GDP (\$ billions) & Trade deficit/GDP (\%) \\
\hline 1960 & 3508 & 526.4 & 0.7 \\
1969 & 91 & 984.6 & 0.0 \\
1973 & 1900 & 1382.7 & 0.1 \\
1980 & -25500 & 2789.5 & -0.9 \\
1981 & -28023 & 3128.4 & -0.9 \\
1990 & -111037 & 5803.1 & -1.9 \\
2001 & -429519 & 10128.0 & -4.2 \\
2007 & -819373 & 13807.5 & -5.9 \\
\hline
\end{tabular}

Source: Palley (2012b).

helped constrain inflation. For big business, trade opening in the 1980s was viewed favorably as a means of disciplining industrial labor unions and reversing the profit squeeze of the late 1960s and 1970s. In the 1990s, trade opening became part of the logic of creating a 'global production zone' in which American firms could produce and export back to the US, or from which they could source cheaper inputs.

Consequently, in the neoliberal era both policymakers and business have seen trade through the lens of costs and wages. For policymakers, trade openness became a means of constraining inflation. For big business, trade openness was initially a means of disciplining workers, and subsequently it became the center of a strategy aimed at creating a global production zone in which business could access lowest cost labor. This configuration of policymaker and business interests explains why the neoliberal era systematically produced unbalanced trade that culminated in the global financial imbalances problem.

The effects of corporate globalization have been multiple, including: contributing to wage stagnation and the widening of income inequality; fostering the house price bubble crisis; spreading the Great Recession from the US to the rest of the world; and contributing to the stagnation that now besets the US economy.

With regard to wage stagnation and income inequality, corporate globalization put US workers, particularly those in the manufacturing sector, in global competition. The resulting competitive threat was used to intimidate workers into accepting wage suppression, while off-shoring of production contributed to de-industrialization and the loss of higher-paying manufacturing jobs. ${ }^{3}$

With regard to triggering the financial crisis, the effects of corporate globalization (and particularly the effects of the US-China economic relationship) played a critical role in contributing to the extremely weak recovery and expansion following the recession of 2001. The trade deficit drained spending out of the economy, while foreign outsourcing and off-shoring of manufacturing resulted in job loss and investment diversion. These effects generated an unprecedentedly extended jobless recovery which continually threatened to lapse back into recession. That drove the Federal Reserve to lower interest rates to historic lows, which in turn triggered the house price bubble. The bubble

3. The wage suppression and job loss effects in connection with the effects of NAFTA are documented by Bronfenbrenner (2000) and Bronfenbrenner/Luce (2004). Scott (2001) also documents the job costs of NAFTA, while Scott (2012) documents the job costs of trade with China. 
prevented a relapse into recession, but the expansion was still the weakest on record despite the enormous stimulus of the house price bubble (Bivens/Irons 2008). Thus, by accelerating the undermining of the US economy's income and demand generation process, corporate globalization accelerated the surfacing of the contradictions in the neoliberal model. That pushed policymakers into fostering a bubble, the implosion of which triggered the crisis.

Once the crisis broke, the trade deficit played an important role in spreading the crisis globally. First, the global economy was quickly impacted by the decline in US aggregate demand owing to the massive scale of US imports. Second, many countries had recycled their trade surpluses into US real estate and sub-prime investments and they were therefore adversely impacted by the collapse of asset prices.

Lastly, the trade deficit has also played an important role in hindering US recovery. That is because it constitutes a large leakage of demand at a time of AD shortage. In sum, corporate globalization has played a critical role in fostering both the economic crisis and the ensuing stagnation via its impact on wages, income inequality, manufacturing employment, and investment.

Finally, the structural Keynesian narrative also makes clear the role of income distribution and why we now confront stagnation. According to the narrative, the neoliberal model caused wage stagnation and increased income inequality. However, deteriorated income distribution did not trigger the crisis. That is because the demand gap caused by deteriorating income distribution was covered over by the 30 -year credit bubble, which included financing the house price bubble. However, with the bursting of the credit bubble, the effects of deteriorated income distribution have come to the fore because borrowing to fill the demand gap is no longer possible. Income distribution is therefore the dog that barked after the crash and it has now become the cause of stagnation. Though emergency Keynesian policy measures stabilized the economy after the financial crisis of 2009, the economy faces a future of stagnation because income distribution remains unrepaired, creating a structural demand gap.

\section{GATTOPARDO ECONOMICS}

The structural Keynesian story is both comprehensive and readily understandable. Income distribution, the trade deficit, excessive credit, and the house price bubble all play a role in explaining the crisis and the ensuing stagnation. The common sense, coherence, and self-evidence of these factors means they have begun to seep into public discourse. Gattopardo economics serves to capture and undercut that process of discourse change. It is exemplified by the mainstream's discovery of income distribution.

\subsection{Gattopardo economics and income distribution}

Before the crisis, income distribution was a non-issue for mainstream macro economists. Though some may have worried about it for ethical reasons of fairness and justice, none viewed it as significant for purposes of macroeconomic analysis. The economy was viewed as functioning roughly the way a market economy should, generating approximately Pareto efficient outcomes - albeit highly unequal outcomes. The conventional explanation for the increasing inequality was skill-biased technological change that had shifted income distribution in favor of CEOs, financiers, and those with college degrees. The resulting inequality raised issues of social policy, but not issues of macroeconomic efficiency. 
The spread of popular awareness about the role of inequality has prompted a 'gattopardo' move to place inequality within the mainstream's own account of the crisis. The first mainstream account to do this was provided by Raghuram Rajan (2010) in his book, Fault Lines: How Hidden Fractures Still Threaten the World Economy. The essence of Rajan's story is how 30 years of skill-biased technological change caused widening of income inequality and wage stagnation at the bottom. This triggered political discontent that government sought to mollify by increasing ease of access to credit, particularly with regard to mortgages. These measures included interventions via the Community Reinvestment Act (CRA) and via the mortgage financing agencies, Fannie Mae and Freddie Mac. Together, they increased the demand for housing, triggering a house price bubble that drove prices far beyond what households could afford. Government's encouragement of mortgage lending interacted with financial markets that were primed for excess by a steady stream of financial innovation, excessive deregulation, and flawed incentive arrangements. The combination of government policy and amoral financial markets generated a flood of speculative unsound lending that eventually produced the financial crisis when investors became aware of the rottenness. ${ }^{4}$

But let's stop and take a close look at the thesis. The first point to notice is that Rajan's explanation of increased income inequality and wage stagnation is primarily the conventional pre-crisis story of skill-biased technical change. The second point is that Rajan views labor markets as functioning exactly as they should, though unfortunately they produce inequality because of technological developments. The third point is that, according to Rajan, income inequality affects the household distribution of consumption but it has no larger implications for aggregate demand and for macroeconomic functioning. That reduces inequality's role to a political one whereby it prompts interventions that ultimately prove destabilizing. The fourth point is there is a 'bait and switch' quality regarding the treatment of income inequality. The thesis advertises inequality as causing the crisis. Yet the argument is that the crisis was caused by the combination of government intervention in the housing credit market and flawed financial market regulation and governance. The fifth point is that Rajan's story has no explanation of why the crisis has been followed by stagnation. According to the implicit theoretical model, all that should happen is homes are foreclosed and resold, the financial sector writes down the value of its assets, and the economy should quickly return to full employment. The sixth and final point is that there is absolutely no evidence for these claims, as the book is almost devoid of data. Disproving the Rajan thesis is strikingly simple. If government intervention in the housing market via Fannie Mae, Freddie Mac, and the Community Reinvestment Act caused the bubble, why then was there an equivalent bubble in the commercial real estate market where there was no such intervention $?^{5}$ In sum, the Rajan hypothesis is classic gattopardo economics. It introduces income distribution; strips income distribution of macroeconomic significance; and then leaves economic theory exactly as it was before the crisis.

Kumhof and Rancière (2010) provide a second, far more sophisticated gattopardo treatment of income distribution. First, unlike Rajan's book which is pure literary narrative, they construct a dynamic stochastic general equilibrium (DSGE) mathematical

4. The Rajan thesis of populist government intervention in housing and credit markets to counter the impact of rising income inequality was actually first developed by Branko Milanovic (2009).

5. For a detailed, evidence-based critique of the government failure explanation of the crisis, see Palley (2012a: ch6). 
model that they simulate and claim generates plausible simulations. The use of DSGE modeling and simulation immediately makes it appealing to the mainstream. It also obscures the underlying economics as mathematical modeling dominates economic analysis.

Their simulation account of the crisis runs as follows. Income distribution is determined by bargaining. Workers are then subject to a persistent series of adverse bargaining power shocks that lower wages, and they respond by borrowing to maintain their living standard. Their borrowing increases the debt-to-income ratio, which increases the probability of a financial crash.

The most seductive part of the story is the focus on bargaining power as the determinant of income distribution. That clearly parallels structural Keynesian theory, and the focus on lower wages from reduced worker bargaining power parallels aspects of the structural Keynesian account of the crisis. The other seductive aspect of the story is borrowing by workers to maintain living standards, which also appears in structural Keynesian theory and accounts of the crisis. These two aspects are the gattopardo aspects, because scratching the story further shows how the analysis remains fundamentally unchanged.

The Kumhof-Rancière simulation analysis rests on a baseline scenario in which workers suffer 10 consecutive years of surprise negative bargaining power and wage shocks, followed by 20 years of rebuilding bargaining power and wages. That simulation scenario generates 30 years of persistent borrowing that increases debt and the debt-to-income ratio, thereby almost inevitably producing a crash.

Once again, there are several points to note. First, the crash happens because financial markets allow households to keep borrowing for 30 years, do not impose debt limits, and do not adjust ceilings to reflect changes in income. That makes their story one of financial market failure. In their macroeconomic schema, changes in income distribution become a trigger for financial market stupidities, but they have little significance beyond that.

Second, and absolutely critically, the Kumhof-Rancière story has nothing to do with $\mathrm{AD}$ and the $\mathrm{AD}$ effects of crisis. Its emphasis on bargaining-power-induced changes in income distribution tricks readers into thinking it is an income distribution-AD story, but it is not. There is never demand shortage in the economy, either before the crisis or after. Moreover, income distribution does not matter for employment: it merely affects the composition of AD. The economy is always at full employment and $\mathrm{AD}$ is of no significance for employment.

Income distribution effects are limited to unanticipated shocks to income that cause workers to borrow more and accumulate debt that generates rising financial fragility. With regard to full employment and the generation of crisis, it does not matter if the equilibrium wage share starts at 60 percent and falls to 40 percent, or if it starts at 40 percent and falls to 20 percent. That illustrates how marginal the role of income distribution really is.

Third, the model has difficulty explaining the post-crisis stagnation, and only does so by 'assuming' financial crisis destroys 10 percent of the capital stock. This 10 percent number is needed to generate plausible simulated post-crisis output losses, which illustrates how calibrated simulation analysis is an exercise in data fitting. The resulting simulated output losses are plausible but the 10 percent capital stock loss assumption is not. The US did not lose 10 percent of its capital stock in 2008. In effect, as with the Rajan story, the Kumhof-Rancière story has difficulty explaining the post-financial crisis stagnation. That is because both stories rest on financial market failure rather than AD failure, and financial market failure should have been remedied by the post-crisis effects of monetary policy and new financial regulation. That contrasts with the structural Keynesian 
account which emphasizes AD shortage owing to wage stagnation and income inequality which has not been corrected.

\subsection{Gattopardo economics and the theory of consumption}

The Kumhof-Rancière (2010) model also introduces different propensities to consume across households, with workers having a higher propensity to consume than capitalists (owners). This line of argument, albeit with very different policy intent, was introduced by Mankiw (2000) in a pre-crisis paper aimed at justifying zero taxation of profits. Here too we see gattopardo economics at work.

According to Mankiw (2000), there exist 'patient' and 'impatient' households. The former have a low propensity to consume and a high propensity to save, while the latter have the reverse. Like the Kumhof/Rancière (2010) paper, the Mankiw paper is completely devoid of references to the long tradition in Keynesian economics of focusing on differences in propensities to consume across households. That lack of citation is explored further in Section 4 which addresses gattopardo economics and the sociology of citation.

Keynesian theory (Kalecki 1942; Kaldor 1956; Pasinetti 1962) emphasizes classbased differences in propensities to consume, with worker households having a higher propensity to consume. The microeconomic explanation for those differences is the combination of the desire for wealth, which is a normal or luxury good, and differences in relative income (Palley 1993; 2010). This contrasts with Mankiw's (2000) explanation in terms of patience versus impatience which portrays differences as values driven, or possibly even the result of genetic differences. In his view, rich households are rich because they are patient and willing to save to build up wealth. Poor households are poor because they are impatient and unwilling to save.

Mankiw's theory constitutes a revival of Victorian notions of poverty. The poor are poor because of character failings, moral failings, and lack of virtue. The rich are rich because they are virtuous. This constitutes classic gattopardo economics that occupies the issue of differential propensities to consume which has been long-emphasized by Keynesians; presents it as a new insight without any citation of previous argument; and completely twists and changes the significance of the issue.

\subsection{Gattopardo economics and the US trade deficit}

The global financial imbalances are also regarded as an important phenomenon in need of explanation. The structural Keynesian account shows the imbalances as a longdeveloping 30-year phenomenon generated by neoliberal globalization, and the imbalances contributed to both long-term and short-term damage to the US economy. The long-term damage concerned the destruction of manufacturing capacity and the creation of economic conditions that helped sever the link between wage and productivity growth. The short-term damage concerned the massive increase in the China trade deficit in the 2000s that undermined economic recovery by draining demand, investment, and jobs.

The scale of the US trade deficit and its clear destructive effects on US manufacturing necessitates an explanation of the deficit. The dominant gattopardo explanation is the saving glut hypothesis developed by Federal Reserve Chairman Ben Bernanke (2005).

One country's trade deficit is by definition another country's trade surplus. The savings glut hypothesis uses this accounting identity to reframe the global imbalance 
problem as the product of excessive saving by emerging market economies rather than insufficient US saving. The saving glut hypothesis therefore persists with the conventional macroeconomic argument that trade deficits are a saving problem, but rather than blaming the deficit country for too little saving, it flips the explanation and blames the surplus country for too much saving. The essence of the argument, as it pertains to the financial crisis, is that emerging market economies (particularly China) increased their exports and ran large trade surpluses (saving), and that those surpluses in turn lowered US interest rates giving rise to the house price bubble.

The saving glut hypothesis is classic gattopardo economics. That is because the language of 'saving glut' makes it appear as if it is a Keynesian theory of demand shortage. However, the reality is that it has nothing to do with Keynesian economics and demand shortage, and it is actually based on classical macroeconomics and assumes full employment. Though couched in the language of trade and export-led growth, the saving glut hypothesis is actually a purely 'financial theory.' This is reflected in the fact that its analytical focus is interest rates and not offshoring and factory closures.

Analytically, the saving glut hypothesis is an updated global statement of 1930s classical loanable funds interest rate theory that Keynes discredited in his General Theory. Loanable funds theory claims interest rates are determined by demand and supply of saving; trade surpluses are accounted for as saving, and ergo they affect interest rates in an integrated global economy. Hence, Chairman Bernanke's claim that China's trade surplus significantly lowered US interest rates. The putative logic is that China's desire to save via exports generates increased demand for US bonds, which lowered US interest rates.

There are several major problems with the saving glut hypothesis. First, with regard to macroeconomics, the hypothesis rests on the fiction there is such a thing as the 'loanable funds market.' Simple monetary analysis shows the sequence is American purchases of Chinese exports, followed by Chinese recycling of export proceeds into US financial assets. The loans to buy Chinese goods come from American banks which create the money, and China only purchases bonds after the goods have been sold. There is never an exchange of goods for bonds, and it is the US which creates the dollars that finance the trade deficit.

Second, the hypothesis also fails at the microeconomic level. Table 2 shows the vast bulk of Chinese exports are produced by foreign multinationals. Fifty percent of Chinese exports are produced by fully owned foreign subsidiaries, and another 26 percent of exports are produced by joint ventures involving foreign corporations. When viewed in this microeconomic light, it becomes clear that the issue is not Chinese saving but globalization. The US trade deficit and Chinese trade surplus are the inevitable product of corporate globalization.

The real cause of China's trade surplus and the US trade deficit is MNC foreign direct investment in China combined with China's undervalued exchange rate, cheap labor, and lax regulatory standards (including labor and environment). That combination has

Table 2 Decomposition by firm ownership structure of Chinese exports and imports in 2005

All firms Foreign-owned Joint ventures Private domestic State-owned

\begin{tabular}{llllll}
\hline Exports & $100 \%$ & $50.4 \%$ & $26.3 \%$ & $13.1 \%$ & $10.3 \%$ \\
\hline
\end{tabular}

Source: Manova/Zhang (2008). 
made foreign production facilities in China super-competitive internationally, and it is a fundamentally different story from excess saving. Rather than saving too much, as claimed by the saving glut hypothesis, the reality is that Chinese workers are not being paid enough to consume what they produce, and multinational corporations (MNCs) export the surplus they capture. That provides a radically different perspective. China's surplus is not an issue of too much voluntary saving by Chinese households. Instead, it is the result of insufficient demand in China because of wages that are too low, combined with a structure of manufacturing production organized by MNCs for purposes of export.

There are also other problems with the saving glut hypothesis. One is: why was only the US afflicted by it, while other large developed economies like Japan and Germany ran surpluses? That difference suggests it is country trade and industry policies that determine the trade deficit, and not China's saving behavior. Another is that microeconomic theory suggests an aging population like the US should be saving, while a relatively young population like that of China should be borrowing. Yet the outcome is the exact opposite, again suggesting the trade deficit is an issue of trade and industry policy.

The purpose of the saving glut hypothesis is to acknowledge the trade deficit as an issue but to make sure nothing changes. Interpreting the trade deficit as a loanable funds market financial distortion does that. The saving glut hypothesis does not criticize globalization, which remains beneficial according to the theory of comparative advantage. Globalization is not blamed for either wage stagnation or de-industrialization, and having China subsidize its exports via an undervalued exchange rate is even good for the US as it is tantamount to a gift (a 'free lunch') to the US economy. Even the effect of the saving glut on interest rates is good as it supposedly makes capital available to US business at a lower rate. Problems only emerge if the cheap capital is misallocated due to financial market failure. Thus, the conclusion of the saving glut hypothesis is that the trade deficit was not even bad: it was only financial market misallocation that was a problem. This is gattopardo economics with a vengeance.

Finally, it is difficult to dispel the saving glut hypothesis for three reasons. First, the description of the problem as a 'saving glut' is brilliantly confusing. It conjures up Keynesian arguments of demand shortage, when in fact there is no connection to Keynesian theory or policy recommendations. Second, exposing the saving glut argument is complex, involving exposing the loanable funds theory of interest rates and the failure of the saving glut hypothesis to fit the facts. Third, the saving glut hypothesis argues that the trade deficit caused lower US interest rates, but so does the structural Keynesian hypothesis. However, structural Keynesian reasoning is completely different. It argues that the flood of Chinese imports weakened US manufacturing and the domestic economy. That caused the Federal Reserve to lower interest rates to ward off a double-dip recession in 2001-2004, while the economic weakness also contributed to lower interest rates by lowering inflation expectations. This is the Keynesian channel (China caused US economic weakness) and it is completely different from the saving glut story (China pumped up the bond market). That difference is difficult to convey.

In sum, the saving glut hypothesis is built on incoherent macroeconomics, incoherent microeconomics, and does not fit the facts. Its purpose is to defuse the trade deficit issue so that international trade and globalization is not blamed for contributing to the crisis. It is brilliant gattopardo economics as it cleverly confuses debate by adopting the language of a Keynesian critique of globalization, but it is neither Keynesian nor critical of globalization. 


\subsection{Gattopardo economics and inflation}

The fourth example of gattopardo economics concerns inflation and inflation policy. The last 30 years have witnessed the intellectual dominance of Milton Friedman's (1968) theory of the natural rate of unemployment. That theory, when combined with the assumption of rational expectations, holds that the Phillips curve is vertical in unemployment rate-inflation space and that monetary policy cannot systematically lower the unemployment rate. Since inflation is undesirable and monetary policy cannot systematically lower unemployment, the resulting policy consensus has been that monetary policy authorities should target steady low inflation of about 2 percent.

Keynesians have persistently criticized this position, arguing that there is a long-run Phillips curve trade-off and a 2 percent inflation target is too low and produces unnecessary costly unemployment. In my own work (Palley 1998; 2006), I have argued for an inflation target in the US of between 3 and 5 percent.

Now, in the wake of the crisis, IMF Chief Economist Olivier Blanchard (Blanchard et al. 2010) has suggested that central banks pursue a higher inflation rate of 4 percent. That looks a lot like the Keynesian position, but once again it is gattopardo economics that changes to keep things the same.

The Blanchard argument is constructed with reference to the zero lower bound (ZLB) on nominal interest rates. It is illustrated in Figure 3. The argument is that a 2 percent inflation target does not leave monetary authorities with enough room to lower the nominal interest rate in the event of a large AD shock. Thus, suppose the equilibrium real interest rate is 3 percent and inflation is equal to the target of 2 percent. That implies a 5 percent nominal rate. Now, suppose there is a large $\mathrm{AD}$ shock that requires a negative real interest rate of minus 3 percent for full employment. With a 2 percent inflation target, that requires a nominal rate of minus 1 percent, which is not possible owing to the ZLB. However, it would be possible if the inflation target were 4 percent, in which case lowering the nominal rate to 1 percent would achieve a real rate of minus 3 percent.

There are three important points to notice. First, the Blanchard argument asserts that monetary authorities may need to adjust real interest rates by 6 percentage points or more over the course of the cycle. That suggests the real economy is very unstable, which is counter to mainstream claims about the stability of market economies. Second, the ZLB serves as a convenient 'whipping boy' for explaining why the macro

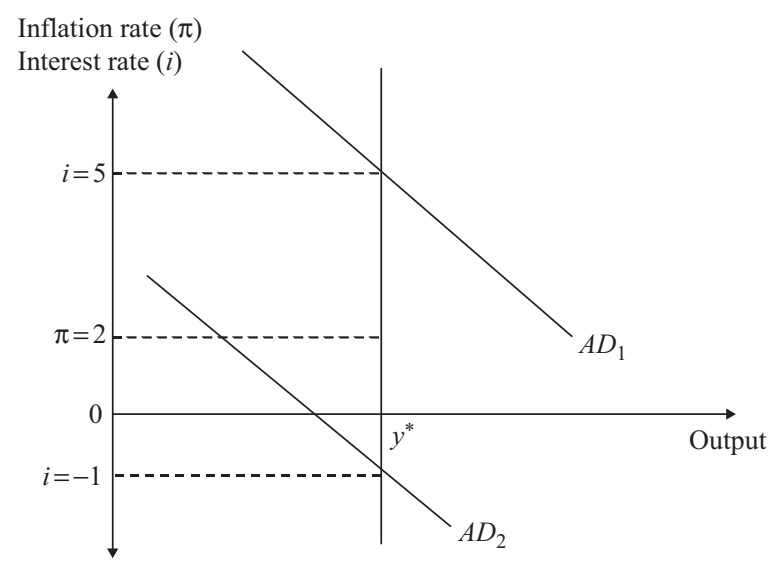

Figure 3 The zero lower bound argument for a higher inflation target $\left(\mathrm{AD}_{1}>\mathrm{AD}_{2}\right)$ 
economy has not returned to full employment. In doing so, it provides cover for not looking for deeper explanations of stagnation. Third, and most important, Blanchard's analysis continues to maintain Friedman's (1968) natural rate of unemployment hypothesis. That means it continues to assert that there is no Phillips curve trade-off between inflation and unemployment, and that monetary policy cannot systematically impact the unemployment rate. Worse yet, by preserving the natural rate hypothesis, it preserves the justification for the labor market flexibility agenda that has been so responsible for wage stagnation and rising income inequality by attacking worker supports like unions, collective bargaining, and the minimum wage. This exemplifies gattopardo economics: occupy the policy space held by Keynesians while leaving deep theory and structural policy unchanged.

\section{GATTOPARDO ECONOMICS AND THE SOCIOLOGY OF CITATION}

The final feature of gattopardo economics concerns its sociology of citation. The macroeconomic effects of income distribution (Kalecki 1942; Pasinetti 1962; Harris 1974), consumer debt as a support of AD (Palley 1997; 2002; 2009; 2012a; Cynamon/Fazzari 2008; Barba/Pivetti 2009), keeping-up-with-the-Joneses consumption behavior and the consumption implications of wealth in the utility function (Duesenberry 1949; Palley 1993; 2010), and the case for a higher inflation target (Palley 1998; 2006) have all been written about extensively by Keynesians and post-Keynesians. Yet none of this literature is cited in the new mainstream work on these issues. There are good reasons for this. Citation authorizes and warrants the work of others. Consequently, failure to cite is a way of denying intellectual legitimacy to intellectual competitors.

A second gattopardo citation strategy, evident in work on endogenous growth theory and financial crises, is to cite a seminal historical contributor but ignore all subsequent work in that vein. For example, in endogenous growth that means citing Kaldor (1957); in financial crisis theory it means citing Minsky (1982); and in consumption theory it means citing Duesenberry (1949). Such a citation strategy captures the founding figure and lays claim to intellectual lineage, while keeping suppressed rival work that would deliver real change. ${ }^{6}$

\section{CONCLUSION: WHY EXPOSING GATTOPARDO ECONOMICS MATTERS}

The structural Keynesian account of the economic crisis makes clear the role of mainstream economists and the neoliberal paradigm in creating the crisis. Scratch any side of the neoliberal policy box and you quickly find the ideas of mainstream economists. Corporate globalization was justified by appealling to economists' comparative advantage theory of free trade. The labor market flexibility agenda was justified by economists' claims that unions and the minimum wage cause unemployment. The retreat from full employment was justified by Friedman's theory of the natural rate of unemployment which implied central banks should focus on low inflation as they cannot permanently affect unemployment. The attack on government and regulation was supported by Chicago School claims that costs of market failure are small relative to the costs of

6. Van Treeck (2012) provides a detailed case study showing how the relative income theory of consumption has been incorporated into mainstream accounts of the crisis without reference to work by Keynesian economists emphasizing this theme over the past 30 years. 
government failure and policy-induced market distortions. Government was also charged with diminishing freedom and paving 'the road to serfdom,' so that freedom was best served by a minimalist government or night-watchman state. Financial deregulation was justified by claims that it would produce a free lunch by increasing efficiency of resource allocation.

After the financial crisis of 2008, many Keynesian economists hoped there would be a profound change of theory within the economics profession. The profession stood discredited owing to its complete failure to anticipate the crisis, whereas Keynesian economists had anticipated the crisis and also showed how neoliberal economics contributed to it. However, change has been minimal.

That should not surprise anyone. Neoliberal economics supports the economic and political interests of powerful elites, and those elites have reason to defend it and block change. Even if only subconsciously, professional economists also have a private (utility-maximizing) interest in maintaining neoliberal ideas to the extent that they are intellectually invested in those ideas and their careers have been built on them.

Society is now engaged in a war of ideas, the outcome of which will greatly influence the future. That is because the way we explain the crisis will influence the direction of future economic policy. Gattopardo economics is one of the mechanisms for blocking intellectual change. It works by muddying the waters and appearing to offer change when in fact it keeps everything the same. That is why it is so important to expose gattopardo economics.

\section{REFERENCES}

Barba, A., Pivetti, M. (2009): Rising household debt: its causes and macroeconomic implications a long period analysis, in: Cambridge Journal of Economics, 33(1), 113-137.

Bernanke, B.S. (2005): The global saving glut and the US current account deficit, the Sandridge lecture, Virginia Association of Economics, Richmond, VA, 10 March.

Bivens, J., Irons, J. (2008): A feeble recovery: the fundamental economic weaknesses of the 2001-07 expansion, EPI Briefing Paper No. 214, Economic Policy Institute, Washington, DC, December.

Blanchard, O., Dell'Arica, G., Mauro, P. (2010): Rethinking macroeconomic policy, Research Department, IMF Staff Position Note SPN/10/03, Washington, DC.

Bronfenbrenner, K. (2000): Uneasy terrain: the impact of capital mobility on workers, wages, and union organizing, Report prepared for the United States Trade Deficit Review Commission, Washington, DC, September.

Bronfenbrenner, K., Luce, S. (2004): The changing nature of corporate global restructuring: the impact of production shifts on jobs in the US, China, and around the globe, Report prepared for the US-China Economic and Security Review Commission, Washington, DC, October.

Cynamon, B., Fazzari, S. (2008): Household debt in the consumer age - sources of growth and collapse, in: Capitalism and Society, 3(2), 1-30.

Duesenberry, J.S. (1949): Income, Saving and the Theory of Consumption Behavior, Cambridge, MA: Harvard University Press.

Duménil, G., Lévy, D. (2011): The Crisis of Neoliberalism, Cambridge, MA: Harvard University Press.

Foster, J.B., Magdoff, F. (2009): The Great Financial Crisis: Causes and Consequences, New York: Monthly Review Press.

Friedman, M. (1968): The role of monetary policy, in: American Economic Review, 58(May), $1-17$.

Harris, D.J. (1974): The price policy of firms, the level of employment, and distribution of income in the short run, in: Australian Economic Papers, 13(22), 144-151. 
Kaldor, N. (1956): Alternative theories of distribution, in: Review of Economic Studies, 23(2), 83-100.

Kaldor, N. (1957): A model of economic growth, in: Economic Journal, 67(268), 591-624.

Kalecki, M. (1942): A theory of profits, in: Economic Journal, 52(206/207), 258-267.

Kumhof, M., Rancière, R. (2010): Inequality, leverage and crises, IMF Working Paper WP/10/268, Washington, DC.

Mankiw, N.G. (2000): The savers-spenders theory of fiscal policy, in: American Economic Review, 90(2), 120-125.

Manova, K., Zhang, Z. (2008): China's exporters and importers: firms, products, and trade partners, Unpublished manuscript, Department of Economics, Stanford University, CA, June.

Milanovic, B. (2009): Two views on the cause of the global crisis - part 1, in: YaleGlobal Online Magazine, 4 May.

Minsky, H.P. (1982): Can It Happen Again? Essays on Instability and Finance, Armonk, NY: M.E. Sharpe.

Palley, T.I. (1993): Under-consumption and the accumulation motive, in: Review of Radical Political Economics, 25(March), 71-86.

Palley, T.I. (1997): Endogenous money and the business cycle, in: Journal of Economics, 65(2), 133-149.

Palley, T.I. (1998): Zero is not the optimal rate of inflation, in: Challenge, 41(January-February), 7-18.

Palley, T.I. (2002): Economic contradictions coming home to roost? Does the US face a long term aggregate demand generation problem?, in: Journal of Post Keynesian Economics, 25(Fall), 9-32.

Palley, T.I. (2005): The questionable legacy of Alan Greenspan, in: Challenge, 48(6), 17-31.

Palley, T.I. (2006): Monetary policy in an endogenous money economy, in: Arestis, P., Sawyer, M. (eds), A Handbook of Alternative Monetary Economics, Cheltenham, UK: Edward Elgar, 242-257.

Palley, T.I. (2008): America's exhausted growth paradigm, in: The Chronicle of Higher Education, Section: The Chronicle Review, 54(31), B10, 11 April.

Palley, T.I. (2009): America's exhausted paradigm: macroeconomic causes of the financial crisis and Great Recession, New America Foundation, Washington, DC, July. Short version reprinted in Empirica, 38(1), 2011, 3-17.

Palley, T.I. (2010): The relative permanent income theory of consumption: a synthetic KeynesDuesenberry-Friedman model, in: Review of Political Economy, 1(January), 41-56.

Palley, T.I. (2012a): From Financial Crisis to Stagnation: The Destruction of Shared Prosperity and the Role of Economics, New York, NY: Cambridge University Press.

Palley, T.I. (2012b): Explaining global financial imbalances: a critique of the saving glut and reserve currency hypotheses, in: From Crisis to Growth: The Challenge of Debt and Imbalances, Marburg, Germany: Metropolis-Verlag, 145-168.

Pasinetti, L. (1962): Rate of profit and income distribution in relation to the rate of economic growth, in: Review of Economic Studies, 29(4), 267-79.

Rajan, R.G. (2010): Fault Lines: How Hidden Fractures Still Threaten the World Economy, Princeton, NJ: Princeton University Press.

Scott, R.E. (2001): NAFTA at seven: its impact on workers in all three nations, Briefing Paper, Economic Policy Institute, Washington DC, April.

Scott, R.E. (2012): The China toll: growing US trade deficit with China cost more than 2.7 million jobs between 2001 and 2011, with job losses in every state, Briefing Paper, Economic Policy Institute, Washington DC, August.

Van Treeck, T. (2012): Did inequality cause the US financial crisis?, Working Paper No. 2012/91, Macroeconomic Policy Institute (IMK), Dusseldorf, Germany and Journal of Economic Surveys, forthcoming. 